Journal of Education and Vocational Research

Vol. 4, No. 10, pp. 287-292, Oct 2013 (ISSN 2221-2590)

\title{
The Effects of Malaysian Hotels Services on Customer Loyalty
}

\author{
Yousef Keshavarz*, Hossein Nezakati \\ Universiti Putra Malaysia (UPM), Malaysia \\ *yousef.k73@gmail.com
}

\begin{abstract}
In recent years, the tourism industry has become more important in terms of the global economy. It is revealed that inbound tourism has become one of the major trade categories. Like other countries in Malaysia several industries involve to attract tourists in the country. The hotel industry is one of these industries affects tourists to be satisfied and desire to visit the place again. Service quality is the most important factor by which hotels influence their guests to be loyal; therefore in this study the effect of service quality on tourist loyalty will be investigated. Factors of service quality, which affected from the expected service quality and affect tourist loyalty, include tangible, reliability, responsiveness, assurance and empathy. In this study, guests of hotels, apartments and budget hotels are considered as the research population and 500 respondents from both domestic and international tourists are selected by clustering sampling. The finding of this study is helpful for hoteliers to understand the demands of their customer from different countries with different cultures and plan new strategies to meet their needs and influence them to be loyal on hotels.
\end{abstract}

Keywords: Hotel industry, service quality, guest loyalty, Malaysian tourist industry

\section{Introduction}

Service sector which were limited in scope and nature until twentieth century changed and enter to sphere of human activity such as insurance, welfare, information technology, hotel and etc. and approximately twothirds of GNP from most countries specially developed ones are accounted by this sector(Sandhu \& Bala, 2011). As other industries, hotels are faced competitive environment to serve increasing number of tourists especially in Malaysia(UNWTO, 2011). It is shown that around $45 \%$ of tourists daily expenditures are expended on accommodation and $91 \%$ of this is directly spent in international tourist hotels(Hsieh \& Lin, 2010). Hotel managers need to find strategies to win in competition with rivals. It is shown that $78 \%$ of executives in western countries and Japan believe that the key factor in hotel to compete with others is service improvement(Lin, 2005). Hotel industry in Malaysia is one of the most important industries which help to tourist industry, hence economic development in country. Since 2008 when 566 hotels were registered in Malaysia, so many hotels have built and the rate has continuously increased (Radzi, Zahari, Muhammad, Aziz, \& Ahmad, 2011). So in 2012 there were 1736 qualified hotels, apartments and budget hotelsin Malaysia (malaysia, 2012).These hotels make all their effort to promote their share in Malaysian hotel industry by attracting more tourists from both domestic and international groups. Therefore they must have strategic plan to affect them to be satisfied and loyal to hotel. In this research try to know the most important factors by which hoteliers affect exist and potential customers to choose the hotel as their best selection for stay and be loyal to the hotel. In particular this research tries to answer following questions:

- What variables are important to use by Malaysian hotels to affect their customers perceive about services quality?

- Which variables in Malaysian hotels do affect tourist to be satisfied?

- What factors in Malaysian hotels do influence on tourist`s loyalty?

\section{Research Background}

Lovelock (1983) stated that hotels based on services have five characteristics include:

- Tangible and intangible services provided by hotels for visitors` bodies and mind respectively

- Hotels get membership in purpose of relationship with customer for both separate and continue service delivery. 
- Hoteliers want to be recognized as high level of customer service provider and low level in personnel contact exercise to meet customer needs.

- Demand for hotels is widely fluctuated over time.

- The way of providing service influence hotels to attract customers.

Chan and Wong (2006) argued that hotel service attributes which is mentioned in several research, are divided in two categories including intangible attribute such as dependability, security, reputation, service quality and staff behavior and tangible attributes such as appearance of facilities, price, word of mouth, advertising , communication past experience and familiar name. Ten basic categories to evaluate service quality includes: reliability, responsiveness, competence, access, courtesy, communication, credibility, security, understanding and knowing the customer and tangibles and they called it SERVQUAL(Parasuraman, Zeithaml, \& Berry, 1985). In 1988 they simplify these multiple item scales to five dimensions includes: tangibles, reliability, responsiveness, assurance; and empathy(Parasuraman, Zeithaml, \& Berry, 1988). After their survey about dimensions of SERVQUAL they defined these five dimensions include:

- Tangibles: equipment, physical facilities and appearance of personnel are defined as tangible dimensions

- Reliability: ability to perform expected service which promised dependably and accurately

- Responsiveness: this dimension is defined as "willingness to help customers and provide prompt service".

- Assurance: Employees with courtesy and knowledge who able to inspire confidence and trust (process)

- Empathy: Individualized attention and caring provided by company to its customers

SERVQUAL model was modified during the time. For example(Ting, 2003) used SERVQUAL technique to provide gap between customer expectation of service quality and service provided in hotel industries and guide hotel managers to improve the quality. Ekinci, Prokopaki, and Cobanoglu (2003) used modified SERVQUAL to realize that customers are more interested from intangible service qualities than tangible. They conclude that customers choose hotels based on location, facilities, service quality, consumption price, hotel reputation, exterior appearance and security respectively. Saleh and Ryan (1991) found five dimensions in hotel industry as service quality dimensions called conviviality, tangibles, reassurance, empathy and avoid sarcasm that were different from SERVQUAL method. Conviviality was recognized as the most important dimension in this research. SERVQUAL was used as a basic to develop and design LODGSERV instrument by Knutson, Stevens, Wullaert, Patton, and Yokoyama (1990). In this research they used LODGSERV to measure service quality in hotels and five service quality dimension were found called reliability, assurance, responsiveness, empathy and tangible. In this research reliability was released as the best dimension of service quality. Mey, Akbar, and Fie (2006) did research in Malaysian hotels by using modified SERVQUAL model to assess the Asian and non-Asian guests` perception and expectation. It is found from the research that, although it was not significant different wit Asian customers in all five dimensions (reliability, responsiveness, assurance, empathy and tangibility), the Malaysian expectation between Malayan with nonAsian customers were significantly different. In term of perception there were not different between Malayan and Asian customers except in assurance dimension however the differences between Malayan and nonAsian customers were significant and it was same for customer satisfaction. Cleanliness, spacious, comfort and well-maintained rooms, convenient location and accessibility, safety and security and room facilities such as safety features in the bathrooms, better lighting, easy to handle door knobs, supporting mattresses and chairs are categorized as intangible aspect of hotel service. In addition courteous and prompt service quality, convenient parking, food value of restaurant exterior aesthetics and interior décor are provided by researches as major contributors of hotels which affect customer satisfaction(Poon \& Low, 2005).

In research carried out by Jaafar, Abdul-Aziz, Maideen, and Mohd (2011) chaos and complexity theory was provided to explain the complexity of relationship between elements of tourism system. Therefore they believed that entrepreneur characteristics were the important factor for tourist development.Anderson and Simester (2004)argued that customer react toward unfairness issues is more drastic than fairness matters and they will be distressed when they face perceived that price is unfair. In fact this issue contributes to emotional part in financial decision making. Refer perceived price fairness is defined by Xia, Monroe, and Cox 
(2004) as assessment and associated emotions of customer to answer the question whether the difference and coequality of between hotels' and room rates are acceptable, reasonable or justifiable. (Radzi et al., 2011). Customer loyalty is defined as "customer intention or actual behavior to repeatedly purchase certain product or services"(Nezakati \& Keshavar, 2012).Loyalty is considered as two aspects. Although some researchers had recognized it as behavioral aspects (Auh\& Johnson, 2005; Cyr, Head\& Ivanov, 2007; Oliver, 1999), concept or attitudinal aspect of loyalty is also considered by other researchers (Balabanis, Reynolds, \& Simintiras, 2006; Bloemer, Ruyter \& Wetzels, 1999; Carpenter\& Fairhurst, 2005). There are several researches had supported the idea that satisfaction lead to loyalty (Heitmann, Lehmann \& Herrmann, 2007; Zeithaml, Berry, \& Parasuraman, 1996). Therefore in this research try to investigate the effect of variables such as perceived service quality and expected service quality on tourist satisfaction and the effect of tourists satisfaction on tourist loyalty in Malaysian hotels, apartments and budget hotels.

Hypotheses and model: According to previous literature the main hypothesis and model in which the relationship between variables recognized are provided below:

H1: expected service quality has significant affect on perceive service quality

H2: perceived service quality has significant affect on tourist satisfaction

H3: expected service quality has significant affect on tourist satisfaction

$\mathrm{H} 4$ : tourist satisfaction has significant affect on tourist loyalty.

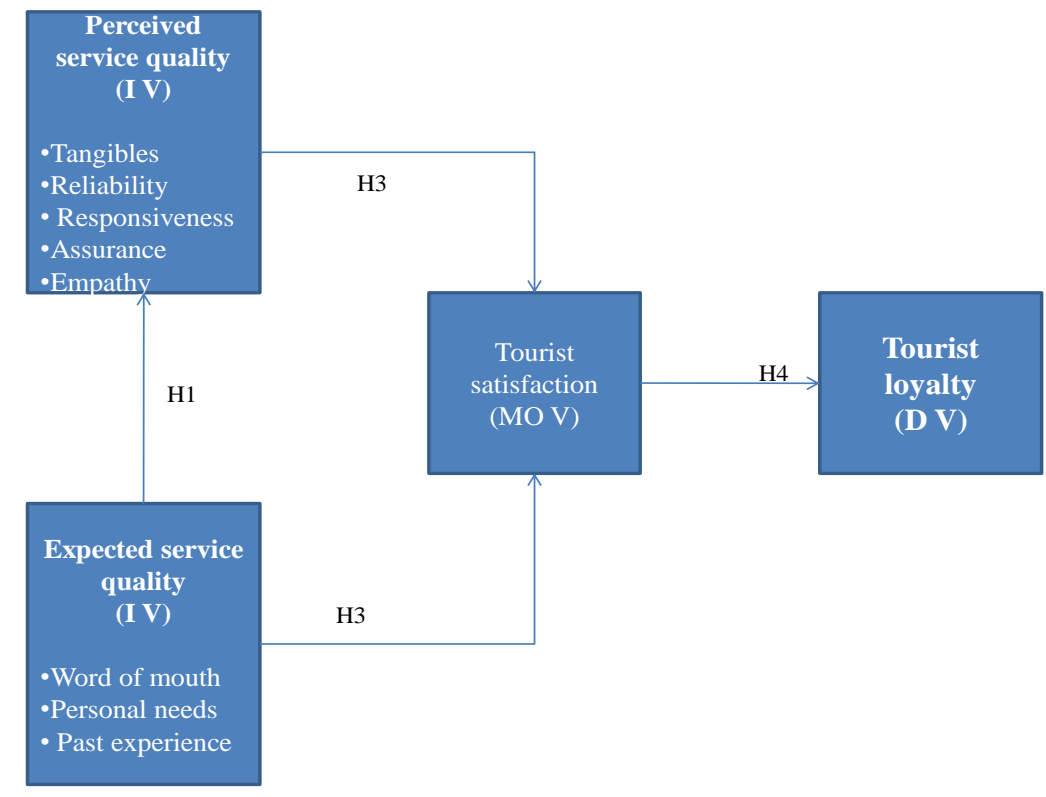

\section{Methodology}

In this research a quantitative method and for data gathering, self-administered questionnaire will used. Domestic and international tourists who are staying in hotels (from1 to 5 stars), apartments and budget hotels in nationwide of Malaysia are chosen as the samples. Table 1 shows the detail information about hotels apartments and budget hotels in Malaysia base on states. Therefore based on above information sampleing method which is used to select the respondents from all hotels, apartments and budget hotels in malaysia is clustring by which first hotels, apartments and budget hotels are selected by random and in selected hotels, apartments and budget hotels respondents will be selected. To gather data questionnair will used. This questionnaire is divided in to three parts. First part is designed to collect data from Malaysian hotels tourists` expectation and perception about hotel services and in the second part their satisfaction from services and loyalty toward hotel is evaluated. The third part is designed to collect demographic information. This section covers the demographic variables, including ethnic group, religion, gender, age, marital status, education level, employment status, occupation, and income level. In this research variables which affect perceived service quality are provided from the modified SERVQUAL model of Parasuraman and other factors based on 
the literature and researcher experience added to develop the new model. These factors are: Expected service quality which has 3 dimensions includes word of mouth, personal needs and past experience.

- Dimensions of service quality include Tangibles, Reliability, Responsiveness, Empathy, and Assurance

- Tourist satisfaction, as one of the most important factors provided in several researches and affected from perceived service quality(Cronin, Brady, \& Hult, 2000; Liat \& Rashid, 2011)

- Tourist loyalty, this factor is a common factor which is provided in several studies(Oliver, 1999; Skogland \& Siguaw, 2004; Tanford, Raab, \& Kim, 2012; Weber, 2001)

Table 1: Number of Hotels, Apartments and Budget Hotels in Malaysia

\begin{tabular}{|c|c|c|c|c|c|c|c|c|c|c|}
\hline \multirow[t]{2}{*}{ Row } & \multirow[t]{2}{*}{ States } & \multicolumn{7}{|c|}{ Hotel } & \multirow[t]{2}{*}{ Budget hotel } & \multirow[t]{2}{*}{ Total } \\
\hline & & 1* & $2 *$ & 3* & 4* & $5^{*}$ & Total & Apartment & & \\
\hline 1 & & 1 & 1 & 0 & 1 & 0 & 3 & 0 & 3 & 6 \\
\hline 2 & Perlis & 9 & 13 & 16 & 10 & 9 & 57 & 0 & 21 & 78 \\
\hline 3 & P. Pinang & 5 & 17 & 8 & 18 & 8 & 56 & 0 & 32 & 88 \\
\hline 4 & Perak & 14 & 22 & 13 & 6 & 1 & 56 & 1 & 69 & 126 \\
\hline 5 & Selangor & 24 & 19 & 18 & 11 & 13 & 85 & 0 & 53 & 138 \\
\hline 6 & N. Sembilan & 6 & 6 & 8 & 9 & 0 & 29 & 5 & 19 & 53 \\
\hline 7 & Melaka & 16 & 17 & 12 & 7 & 3 & 55 & 1 & 67 & 123 \\
\hline 8 & Johor & 20 & 29 & 21 & 9 & 4 & 83 & 1 & 62 & 146 \\
\hline 9 & Pahang & 12 & 24 & 24 & 15 & 4 & 79 & 1 & 79 & 159 \\
\hline 10 & Kelantan & 2 & 13 & 6 & 1 & 1 & 23 & 0 & 41 & 64 \\
\hline 11 & Terengganu & 5 & 14 & 9 & 3 & 4 & 35 & 0 & 48 & 83 \\
\hline 12 & Sabah & 41 & 42 & 35 & 15 & 9 & 142 & 1 & 105 & 248 \\
\hline 13 & Sarawak & 18 & 13 & 25 & 13 & 6 & 75 & 1 & 125 & 201 \\
\hline 14 & K. Lumpur & 28 & 35 & 27 & 19 & 24 & 133 & 14 & 55 & 202 \\
\hline 15 & Putrajaya & 0 & 0 & 0 & 1 & 2 & 3 & 0 & 0 & 3 \\
\hline 16 & Labuan & 4 & 7 & 1 & 1 & 2 & 15 & 0 & 3 & 18 \\
\hline Total & & $\begin{array}{l}20 \\
5\end{array}$ & $\begin{array}{l}27 \\
2\end{array}$ & $\begin{array}{l}22 \\
3\end{array}$ & $\begin{array}{l}13 \\
9\end{array}$ & 90 & 929 & 25 & 782 & 1736 \\
\hline
\end{tabular}

Source: malaysia (2012)

Sample size: Sample is representative of population (Greener, 2008). Large sample size affect on generalize the findings o the population and minimize the error. Therefore in sample setting sample for statistical analysis and for any category must be determined (Green, 1991). According to Green (1991) estimate sample size for multiple regression is $\mathrm{N}=50+8(\mathrm{~m})$. In this formula $\mathrm{N}$ is sample size and $\mathrm{m}$ is the number of indicators. In this research there are 10 indicators. Therefore based on mentioned formula the number of 
sample size is $50+8(10)=130$. Therefore the minimum sample size for this study is 130 , but to avoiding of statistical error at least 300 respondent will selected as sample.

\section{Conclusion}

The importance of customer satisfaction and loyalty is provided by many researches and it has believed that affect firms to have competitive advantage ( see for example Abdul-Rahman \& Kamarulzaman, 2012; Anderson, E. W., \& Sullivan, 1993; Rauyruen, \& Miller, 2007; Yi, \& La, 2004). Therefore, in this study, try to investigate the factors in hotels, apartments and budget hotels which affect on tourist satisfaction and loyalty.The result of this study is useful for hotelier to make new strategy base on their guest attitude, because this research reveal the factors which is important for tourists to be satisfied and loyal to hotel. In fact in this research the dimensions of service quality and their affects on tourist satisfaction and loyalty are investigated.

\section{Reference}

Abdul-Rahman, M. \& Kamarulzaman, Y. (2012). The Influence of Relationship Quality and Switching Costs on Customer Loyalty in the Malaysian Hotel Industry. Procedia-Social and Behavioral Sciences, 62, 10231027.

Anderson, E. \& Simester, D. (2004). Charging different prices for the same item: Do fairness concern impact future demand. (phd), Kellogg School of Management, Unpublished doctoral dissertation.

Auh, S. \& Johnson, M. D. (2005). Compatibility effects in evaluations of satisfaction and loyalty. Journal of Economic psychology, 26(1), 35-57.

Balabanis, G., Reynolds, N. \& Simintiras, A. (2006). Bases of e-store loyalty: Perceived switching barriers and satisfaction. Journal of Business Research, 59(2), 214-224.

Bloemer, J., De Ruyter, K. O. \& Wetzels, M. (1999). Linking perceived service quality and service loyalty: a multi-dimensional perspective. European Journal of Marketing, 33(11/12), 1082-1106.

Carpenter, J. M. \& Fairhurst, A. (2005). Consumer shopping value, satisfaction, and loyalty for retail apparel brands. Journal of Fashion Marketing and Management, 9(3), 256-269.

Chan, E. S. W. \& Wong, S. C. K. (2006). Hotel selection: when price is not the issue. Journal of Vacation Marketing, 12(2), 142-159.

Cronin, J. J., Brady, M. K. \& Hult, G. T. M. (2000). Assessing the effects of quality, value, and customer satisfaction on consumer behavioral intentions in service environments. Journal of retailing, 76(2), 193-218.

Cyr, D. H., Head, K. M. \& Ivanov, A. (2007). The role of social presence in establishing loyalty in e-Service environments. Interacting with Computers, 19(1), 43-56. doi: 10.1016/j.intcom.2006.07.010

Ekinci, Y., Prokopaki, P. \& Cobanoglu, C. (2003). Service quality in Cretan accommodations: marketing strategies for the UK holiday market. International Journal of Hospitality Management, 22(1), 47-66.

Green, S. B. (1991). How many subjects does it take to do a regression analysis. Multivariate behavioral research, 26(3), 499-510.

Greener, S. (2008). Business Research Methods.[e-book] Dr. Sue Greener and Ventus Publishing ApS. Available through:<http://www. bookbon. com $>$ [Accessed 9 May 2011].

Heitmann, M., Lehmann, D. R. \& Herrmann, A. (2007). Choice goal attainment and decision and consumption satisfaction. Journal of Marketing Research, 3, 234-250.

Hsieh, L. F. \& Lin, L. H. (2010). A performance evaluation model for international tourist hotels in Taiwan-An application of the relational network DEA. International Journal of Hospitality Management, 29(1), 14-24. doi: 10.1016/j.ijhm.2009.04.004

Jaafar, M., Abdul-Aziz, A. R., Maideen, S. A. \& Mohd, S. Z. (2011). Entrepreneurship in the tourism industry: Issues in developing countries. International Journal of Hospitality Management, 30(4), 827-835.

Knutson, B., Stevens, P., Wullaert, C., Patton, M. \& Yokoyama, F. (1990). LODGSERV: A service quality index for the lodging industry. Journal of Hospitality \& Tourism Research, 14(2), 277-284.

Liat, C. B. \& Rashid, M. Z. A. (2011). A Study Of Service Quality, Customer Satisfaction, Corporate Image And Customer Loyalty In The Hotel Industry In Malaysia. Paper presented at the Contemporary Research Issues and Challenges in Emerging Economies. 
Lin, C. H. (2005). Relationship between guest perception of service quality and customer loyalty in the hotel industry in south. Lynn university, Florida. (unpublished dissertation)

Lovelock, C. H. (1983). Classifying services to gain strategic marketing insights. The Journal of Marketing, 1, 920.

Malaysia, Ministry of Tourist. (2012). Registerd hotels. Malaysia: ministry of tourist malaysia Retrieved from http://www.motour.gov.my/en/check/registered-hotel.html?hotel=\&negeri=\&rpt.

Mey, L. P., Akbar, A. K. \& Fie, D. Y. G. (2006). Measuring service quality and customer satisfaction of the hotels in Malaysia: Malaysian, Asian and non-Asian hotel guests. Journal of Hospitality and Tourism Management, 13(02), 144-160.

Nezakati, H. \& Keshavar, Y. (2012). To Explore Hotel Service Factors Effect on Increasing Tourist LoyaltyMalaysia Evidence (Preliminary Study). Journal of Education and Vocational Research, 3(12), 415418.

Oliver, R. (1999). Whence consumer loyalty. Journal of Marketing, 63(4), 33-44.

Parasuraman, A., Zeithaml, V. A. \& Berry, L. L. (1985). A concepyual model of service quality and its implications for future research journal of marketing, 49, 41-50.

Parasuraman, A., Zeithaml, V. A. \& Berry, L. L. (1988). SERVQUAL- A Multiple-Item Scale for Measuring Consumer Perceptions of Service Quality. journal of Retailing, 64(1), 12-40.

Poon, W. C. \& Low, K. L. T. (2005). Are travellers satisfied with Malaysian hotels? International Journal of Contemporary Hospitality Management, 17(3), 217-227.

Radzi, S. M., Zahari, M. S. M., Muhammad, R., Aziz, A. A. \& Ahmad, N. A. (2011). The effect of factors influencing the perception of price fairness towards customer response behaviors. Journal of Global Management, 2(1), 22-38.

Rauyruen, P. \& Miller, K. E. (2007). Relationship quality as a predictor of B2B customer loyalty. Journal of business research, 60(1), 21-31.

Saleh, F. \& Ryan, C. (1991). Analysing service quality in the hospitality industry using the SERVQUAL model. Service Industries Journal, 11(3), 324-345.

Sandhu, H. S. \& Bala, M. N. (2011). Customers' Perception towards Service Quality of Life Insurance Corporation of India: A Factor Analytic Approach. International Journal of Business and Social Science, 2(18), 219-231.

Skogland, I. \& Siguaw, J. A. (2004). Are your satisfied customers loyal? Cornell Hotel and Restaurant Administration Quarterly, 45(3), 221-234.

Tanford, S., Raab, C. \& Kim, Y. S. (2012). Determinants of customer loyalty and purchasing behavior for fullservice and limited-service hotels. International Journal of Hospitality Management, 31(2), 319-328. doi: 10.1016/j.ijhm.2011.04.006

Ting, K. H. (2003). A study of factors that influence the hotel service quality. (master ), Chaoyang University of Technology,, Taichung,Taiwan.

UNWTO. (2011). UNWTO Tourism Highlights: World Tourism Organization (UNWTO)

Weber, K. (2001). Association meeting planners' loyalty to hotel chains. International Journal of Hospitality Management, 20(3), 259-275.

Xia, L., Monroe, K. B. \& Cox, J. L. (2004). The price is unfair! A conceptual framework of price fairness perceptions. Journal of marketing, 3, 1-15.

Yi, Y. \& La, S. (2004). What influences the relationship between customer satisfaction and repurchase intention? Investigating the effects of adjusted expectations and customer loyalty. Psychology \& Marketing, 21(5), 351-373.

Zeithaml, V. A., Berry, L. L. \& Parasuraman, A. (1996). The behavioral consequences of service quality. The Journal of Marketing, 2, 31-46. 